\title{
YaoShunism: A New Approach to Politics ${ }^{1}$
}

\author{
Dr Dengsheng Zhang \\ School of Science, Engineering and Information Technology \\ Federation University Australia \\ Churchill, VIC 3842 \\ dengsheng.zhang@federation.edu.au
}

\begin{abstract}
Most of the studies and debates on liberal democracy in literature are centred around what goes wrong with liberal democracy and how to remedy it. However, there is little attention on oriental practice of democracy or viable alternative to western democracy. In this paper, a study is made on ancient Chinese thinking and practice of democracy. It is found that the first democracy was born in China more than 4,000 years ago. As a result of the discovery, a practical framework called YaoShunism is formulated and presented. YaoShunism offers nonpartisan politics and participatory governance. It is backed by major Chinese philosophies and provides a viable alternative to existing political practice. It is shown that the entire world can benefit from YaoShunism if implemented.
\end{abstract}

Keywords: democracy, politics, election, political party, governance, Taoism, Confucianism.

\section{Introduction}

Politics plays a central role in modern societies, it dominates people's lives and determines people's future. History shows that prosperous times are usually coupled with good politics while bad politics often leads to disasters. The planet today is more vulnerable than ever considering the many great challenges faced by humanity, such as, poverty, debt, diseases, pollution, global warming, nuclear arms, terrorism, urban overpopulation, unsustainable growth, inequality, refugees etc. Unfortunately, this backlog is going to get longer given the broken political systems in many countries including major world powers. As pointed out in [1], "We face a potentially grim future. Until solution efforts change to solving the Broken Political System Problem, the world will continue its death-like march toward environmental, economic, and social sustainability catastrophe". The rising of dysfunctional politics, far-right movements and authoritarian regimes around the world in recent years has diminished the hope to tackle those urgent issues.

\footnotetext{
1 (c) Dengsheng Zhang, 2019. All rights reserved.
} 
There are many studies and debates on what goes wrong with liberal democracy $[1,2,3,4,5$, 6]. Alternatives to conventional liberal democracy have also been suggested [7, 8]. However, practical alternatives are still based on partisan politics with political parties and elections at its core. The problem with partisan politics is that political parties have a long history of bad reputation, due to the ways they operate and behave, e.g. collusion, insulting, threat, coercion, sabotage, blackmail and even violence, all of which are typical characteristics of gangs or mafias. These kind of operations and behaviours have scared off good and talented people, especially women, from politics. The raucous and hysterical elections deter even more capable people from politics, because no sane people would want to be part of a political circus. Around the world, people are fed up with political parties and voter turnout for election has been steadily declining for four decades [9]. Voter turnout in some established democracies is dropping toward 50\% including that of US and voter turnout at some countries has already dropped to below $50 \%$, e.g. Switzerland. Indeed, liberal democracy has sunk to so low that many countries like Australia are forcing people to vote and authorities threaten people with prosecution if they don't cast their ballots $[10,11]$.

It is not surprising that liberal democracy is deemed to be a defective and perverted form of governing by Aristotle, widely regarded as the father of modern political science [12,13]. And, Aristotle warned people more than 2,000 years ago that liberal democracy would lead to anarchic mob rule, which is increasingly true given the chaos and turmoils experienced by many countries today. The world has known too well about how political parties and elections can bring destruction to the world. Indeed, most of world dictators and tyrants in the last one hundred years came to power through democratic elections including those of notorious fascist leaders in the past. Today, this cancerous politics appears to make a return elsewhere in the world, prominently in Europe and America.

How to break this vicious cycle and lead humanity to a brighter future has attracted wisdom from all kinds of minds. Albert Einstein once told the world: "A new type of thinking is essential if mankind is to survive and move toward higher levels" [14]. Einstein is right, everything in this world has its limitation just like his physics, partisan politics is no exception, be it liberal democracy or authoritarianism. The world needs to reflect on a new approach to politics.

The rest of the article is organized as following. In Section 2, philosophical thoughts on ethics of partisan practices are first introduced. The practice of first democracy in ancient China is 
then described. In Section 3, a new political approach called YaoShunism is first proposed. Next, the framework of implementing YaoShunism is described in details. In Section 4, the advantages and feasibility of implementing YaoShunism are discussed. The study is concluded in Section 5.

\section{The Way to Rectification}

From the above discussions, we see that the world is on track of a train wreck due to the reckless politics and there is an urgent need for rectification before it's too late. In this paper, we widen our view and go further back into history to explore oriental practice on democracy in ancient China. We want to know what our ancestors had told us and how great rulers in human history ruled their subjects. The aim is to find answers to the political stalemates in modern societies. But first, we look to Lao Tzu and Confucius (two of the great thinkers in $6^{\text {th }}$ century BC) for guidance on The Way (Tao) to good politics. One of Lao Tzu's advices is that we can learn from when human civilization was young just like we can learn from a young child who often reminds our common sense. Another way of understanding of his advice is that early human civilisation is like the mother of human civilisation, and we all need to refresh what our mothers have taught us. All in all, if we understand the coming and going of our history, we will be able to control our fate. The following are some of the quotes from Lao Tzu's work [15]:

- "Hold fast to the ancient Tao (The Way), for then you will command all realities of the present. By knowing the ancient origin, you see the trace of Tao. (in Chinese: 执古之道, 以御今之有。能知古始, 是谓道纪。)”

- "The world has a beginning, the beginning is the mother of the world. Knowing the mother, we know we are her children. Knowing we are her children, we must return to guard the mother so that we will be free from all perils to the end of our lives. (in Chinese: 天下有 始, 以为天下母。既得其母, 以知其子, 复守其母, 没身不殆。)”

- "Thriving things of a million kinds, all return to their roots. Such a return is called tranquillity, and such tranquillity is called return to fate. Such a return to fate is called norm, and to know the norm is wise. Not to know the norm is waywardness, which results in calamity. (in Chinese: 夫物芸芸, 各复归其根。归根曰静, 是谓复命。复命曰常, 知 常曰明。不知常, 妄作凶。)” 
These ideas of Lao Tzu have also been preached in the "The Great Learning" chapter of The Books of Rites: "All things have their root and their branches. All affairs have their end and their beginning. To know what is first and what is next will lead you closer to the Tao (in Chinese: 物有本末, 事有终始。知所先后, 则近道矣。)”.

If Lao Tzu showed us The Way, Confucius instructed us how to get onto The Way. It is from Confucius' teaching that we find how contemporary politics are so wrong and the root causes of political debacles in modern world. The following are a few quotes of Confucius on avoiding partisan behaviour [16].

- "Good people are peaceful and do not fight each other, they get along well but do not form cliques. (in Chinese: 君子矜而不争，群而不党。)”

- "Good people do not always agree yet get along in harmony, while dishonest people (or mean people, people with no moral) speak the same but do infighting. Good people are allembracing and not partisan, while dishonest people are partisan and not inclusive. (in Chinese: 君子和而不同，小人同而不和。君子周而不比，小人比而不周。)”

- "Skilful words and flattering looks are rarely associated with good virtue. (in Chinese: 巧 言令色, 鲜矣仁。)”

The messages are clear in Confucius teaching that good people do not collude to form cliques. Those who form parties and go around manipulating people with tricky words have no moral. Therefore, it's not surprising to see political fighting and infighting a common play in our daily shows.

To eradicate the turmoils and injustice from today's world, political parties and elections must be banned, and YaoShunism must be restored. Yao the Great and Shun the Great were two of the greatest rulers in human history. Their greatness has been well documented in the Records of the Grand Historian [17], the most reputed chronicles of Chinese history. Emperor Yao was the first ruler in Chinese history who voluntarily passed his power to Shun instead of passing it to his own children. It was unprecedented. Shun did the same by passing his power to Yu the Great instead of his own children. In terms of democracy, the fundamental question is: who should rule the state, and according to Plato, the best should rule [18]. Obviously, 'the best' means people with the best moral and mind rather than people with the best rhetoric and trick. Therefore, it can be said that Yao and Shun together created the first democracy more than 4,000 years ago. 
When Yao was getting old, he chaired a meeting with his four advisers to look for his successor, the group is equivalent to a selection committee in modern day. Yao asked them who could be his successor, after eliminating all the other candidates including Yao's eldest son and Yao's relatives, the committee unanimously recommended the 30 years old Shun who was not only the most talented citizen but also the most beloved citizen in the kingdom. Yao accepted their recommendation and appointed Shun to the most important position which was equivalent to the prime minister today. Three years later, Yao abdicated his throne and passed all the powers to Shun who then became the emperor. When Yao died 28 years later, Shun wanted to return the throne to Yao's eldest son, however, people only recognised Shun instead of Yao's son, so Shun kept ruling until abdicating himself and passing his powers to $\mathrm{Yu}$ the Great, who worked extremely hard to eradicate the kingdom from deadly flooding which had plagued the nation for generations.

Confucius had very high regards on both Yao and Shun whose greatness was taught for a number of times in the Analects of Confucius [16]. The following are a few quotes from it:

- "What a great ruler Yao was! Absolutely majestic! Only heaven is great, and only Yao was able to emulate it. His virtue was so great that the people could find no words to describe it. How stunning were his achievements, and how brilliant the culture was that he created! (in Chinese: 大哉, 尧之为君也! 巍巍乎, 唯天为大, 唯尧则之. 荡荡乎, 民无能名 焉。巍巍乎，其有成功也；焕乎，其有文章。”

- "Shun and Yu were so majestic! They reigned over the world yet did not take possession of it. (in Chinese: 巍巍乎, 舜禹之有天下也, 而不與焉。)”

- Yao said, "Ah, you, Shun, the heavenly succession has fallen on you. Hold firm onto it. If the whole realm of your reign falls into dire stress and hunger, the heavenly blessing will end forever.” Shun similarly instructed Yu. (in Chinese: 尧曰: “咨, 尔舜, 天之历数在 尔躬, 允执其中。四海困穷, 天禄永终."舜亦以命禹。”

- "Is not Shun the one who governed without ado? For what did he do? He seated himself reverently, facing the due south. That's all. (in Chinese: 无为而治者, 其舜也与? 夫为 何哉？恭己正南面而已也。)" 
- "When Shun was emperor, he selected Kao Yao from among the people, put him in charge, and the evil people stayed far away. (in Chinese: 舜有天下, 选于众, 举臮陶, 不仁者 远矣。)”

The greatness of both Yao and Shun has also been hailed in many other great Chinese literatures including The Book of Changes [19] and The Book of Rites [20]:

- "After the death of Shen-nong, there arose Emperors Huang, Yao and Shun. They carried through the changes, so that the people did without being wearied; yea, they exerted such a spirit-like transformation, that the people felt constrained to approve the changes as right. When a series of changes has run all its course, another change ensues. When it obtains free course, it will continue long. Hence it was that these sovereigns were helped by Heaven; they had good fortune, and their every movement was advantageous. Emperors Huang, Yao, and Shun just wore their garments, and good order was secured all under heaven. The idea of all this was likely taken from Qian and Kun (heaven and earth, the first and last divinatory trigrams). (in Chinese: 神农氏没，黄帝、尧、舜氏作，通其变，使民不倦， 神而化之, 使民宜之。易穷则变, 变则通, 通则久。是以自天佑之, 吉无不利, 黄 帝、尧、舜垂衣裳而天下治，盖取诸乾坤。）”

- "Yao and Shun led the kingdom with benevolence and the people followed them. Jie and Zhou led the kingdom with violence and the people followed them. (in Chinese: 尧、舜率 天下以仁，而民从之；桀、纣率天下以暴，而民从之。)”

- "His Master Confucius said: "There was Shun: He indeed was greatly wise! Shun loved to question others, and to study the words of those near him. He concealed what was bad in them and displayed what was good. He took hold of their two extremes, determined the Mean, and employed it in his government of the people. It was by this that he was Shun! (in Chinese: 子曰：'舜其大知也与！舜好问而好察迩言, 隐恶而扬善, 执其两端, 用其中于民, 其斯以为舜乎! ' '”

- "His Master Confucius said, "How greatly filial was Shun! His virtue was that of a sage; his dignity was the throne; his riches were all within the four seas. He offered his sacrifices in his ancestral temple, and his descendants preserved the sacrifices to himself. Therefore having such great virtue, he was destined to have the throne, to have those riches, to have his fame, and to attain a long life. (in Chinese: 子曰： '舜其大孝也与! 德为圣人, 尊为 
天子, 富有四海之内。宗庙飨之, 子孙保之。故大德必得其位, 必得其禄。必得其 名, 必得其寿。')"

From the above great Chinese literatures, the following have been learnt about Yao and Shun (YaoShun hereafter):

- They were fair and selfless;

- They loved people like their own family and were loved by people heartily;

- They were the most capable rulers and ruled their kingdom without interference;

- They set the examples of a good leader.

\section{YaoShunism}

The success and greatness of YaoShun are undeniable. Their ideas and approaches are not complex. For thousands of years, rulers and scholars had never stopped looking for ways to replicate the success of YaoShun. Yet, no ruler had ever achieved what YaoShun had done. After kings were deposed, they were replaced by mobs whose greed for kings' power has dashed people's hope of restoring YaoShun's democracy. Today, at this time when the planet is at the crossroad, it is worth a try. The following introduces YaoShunism.

YaoShunism is based on the following four principles:

- Good people don't collude nor do they form cliques

- People's will is the Lord's will

- Only good and talented people are given powers to govern

- Let heavenly blessing be upon all

The following describes the framework to implement YaoShunism.

\subsection{Ban Political Parties}

Political parties have hijacked powers from people since the world became republics. They are like the remnant from the unfinished revolution of deposing the monarchs. As shown in Confucius teaching, political parties are by no means normal and they are actually the root 
causes of the broken political systems around the world. People who collude and form parties are typically cowards, inept and corrupt. It would be absurd to let a country run by people like mobs. Furthermore, many of the social problems today can be attributed to the reckless behaviours of political parties because they set bad examples to a society. For example, the denigration of minorities and migrants by far-right and conservative parties has caused racial discrimination and violence in Europe and America. As said in The Book of Rites "Yao and Shun led the kingdom with benevolence and the people followed them. Jie and Zhou led the kingdom with violence and the people followed them." [20].

Partisan leads to division. Therefore, to implement the first principle of YaoShunism, a country must ban all political parties and political rallies by laws. All political parties are treated as the same criminal organizations as gangs and mafias. Governments at all levels only select and appoint people without any partisan affiliation. Candidates who want to serve in a government and legislature must denounce all partisan associations. A government can fire an official or a public servant on the ground of any partisan association or partisan leaning.

Unions are similar organizations to political parties. They artificially manipulate labour price and their protests disrupt the operations of an economy. Therefore, both unions and their protests must also be banned. Protests are replaced by finger print signatures which are verified for uniqueness and actual number of signatures by authorized third parties. Once the number of signatures has passed a threshold, authority must respond and negotiate with the protesters for an agreement.

\subsection{Ban Elections}

Elections breed manipulations. Elections are becoming more and more hysterical and tricky, they only create more divide and sow more hatred in a society. They are used as smoke screens to manipulate and hijack people's will. Furthermore, elections are also used to cover up politicians' ineptness and their insidious agenda. To the people, a general election nowadays is not much different from a pageant show or a Saturday night lottery draw. And worse yet, in addition to general elections, there are endless referendums, state elections, local elections and by-elections. People are becoming tired of and nervous about elections.

If people do not want to participate in elections, democracy stops to make sense any more. As a matter of fact, the world is becoming less democratic even more countries are holding 
elections [21]. Low turnout in Switzerland and low participation of voluntary voters in Australia and other countries with compulsory voting show that elections have lost their functions or are more like random draws. This random draw effect can be demonstrated by the phenomenon that Australia has had 7 prime ministers in 10 years. Likewise, hung parliaments, minority governments, razor-sharp election results, election re-runs, election run-offs and refusal to concede are also common around the world nowadays. These results cause political stalemates and even violence, people are paying the price. Furthermore, elections often result in wrong parties or wrong leaders coming to power due to low participation from rational and well-informed voters. For many governments and politicians around the world, their main business is to win an election or stay on power instead of solving the countries' problems. The cost and burden of elections to a society is just unimaginable.

Therefore, to implement the second principle of YaoShunism, a country must ban all kind of elections by laws and replace them with opinion polls. A country uses a combination of government and third-party polls to collect people's opinions which are used to measure the performance of both the government and public officials. A well designed poll system can cover all the social groups and effectively capture people's will while prevent it from manipulation at the same time.

\subsection{Selection of Public Servants and Law Makers}

The selection of talented public officials is key to a good governance. The selection of Shun by Yao was based on reputation which is equivalent to an opinion poll today. The selection of Yu by Shun was based on both merit and reputation. By the time of 600AD or Sui dynasty (581-618), imperial examination was systematically used to select public officials in China [22]. Since then, it had been used by all the following dynasties to select public officials until 1905, shortly before China became a republic. The disadvantages of imperial examination are that the closed-book examination favoured rote learning candidates and the examiners were government officials who were biased. However, the importance and impact of imperial exam cannot be overestimated. For one thing, it had changed imperial bureaucracy from thousands of years nepotism to scholarly bureaucrats. And for another, it helped to create four of the longest dynasties in Chinese history, namely, the dynasties of Tang (618-907), Song (9601279), Ming (1368-1644) and Qing (1636-1912). Four of the most prosperous times in Chinese history had also occurred during the four dynasties. Today, with modern technology, 
the advantages of the three selection methods (merit, reputation and examination) can be combined to create an open competition selection system which is described in the following.

\subsubsection{Selection of a Leader}

To implement the third principle of YaoShunism, a leader of a country must be equipped with three qualities: have no partisan association, have a systematic idea of governing the country and beloved by the people. To be a leader, foremost, he/she must present to the country a systematic idea to address the major issues in the country such as industry, agriculture, education, defence, economy, environment, foreign affair, health, welfare etc. He/she must also address the major challenges of the country and how to deal with them. To be a leader, the candidate must also be loved by the people demonstrated by the highest score in the opinion poll. This selection system ensures that a prospective leader needs to accumulate sufficient governing experience before running the country, unless a candidate has exceptionally bright ideas which earn him/her the highest score in the opinion poll.

To emulate YaoShun, a leader must take the selection of a successor as one of his/her major responsibilities. Specifically, the leader should appoint the top three candidates from the opinion polls as his/her deputies to help running the country. At the end of the leader's term, his/her best deputy in the opinion polls will be selected to be the new leader, who will then be ratified by the country's legislature.

Leaders of lower levels of governments can be selected using the same system of selecting the national leader.

\subsubsection{Selection of Public Officials}

A country sets up a web site to publish policy proposals from the public. The publication is divided into a category A journal and a category B journal. Important and selective proposals are published in journal A. Publications on journal A are most potential for legislations and government policies. Journal B is used to publish any other useful and well-argued proposals or opinions from the public. Publications on journal B are for inspiring more ideas from the public and ideas from journal B can be promoted to journal A with further development. Publications on both journal A and B should be organized into different categories such as 
industry, agriculture, education, defence, economy, environment, transportation, energy, foreign affair, health, welfare etc.

The country uses the two journals as the source of ideas and adopts those good ideas as government policies or legislations. Authors of the proposals adopted by the government or legislature will be awarded with government funds to support their further research on local and national issues. In order to encourage public participation in governing, a legislation or policy can be named after the author who has proposed it. Furthermore, the government can hire the author as the project manager or part of the management team if the proposal results in a public project. The journals accept policy proposals from around the globe, international authors will also be rewarded if their proposals are adopted by the government.

The country uses the two journals to attract public servants for the government and select members of the legislature. Every level of governments and legislatures can create their own journals for selection of public servants and law makers. Authors with the most contributions are featured in the website to promote them to the public. People who want to be public servants and law makers can use the journals as opportunities to accumulate experience and gain public recognition in the opinion polls.

A blog or wiki forum should also be created for each of the important policies or legislations, so that the public can comment or debate on its pros and cons. By collecting public opinions on each of the policies and legislations, a country can avoid serious oversights or mistakes in each decision making.

Due to the removal of partisan politics, there is no need for upper house in the legislature. One house is adequate for making fair laws. With a one-house legislature, the balance of power can be achieved more effectively. For example, if the house believes the president has committed a crime and more than two thirds of the house members support an impeachment, it then goes to the Supreme Court or Constitutional Court for a fair judgement instead of going to the upper house whose judgement cannot be fair. Without partisan politics, the confrontation between the executive branch and the legislative branch is removed. There is no need for endless confirmation hearing and testifying from government officials. The operation of the country is much more efficient than current hostile approach.

With this selection system in place, public servants and law makers are selected based on their talent, merit and reputation instead of on how well they do political barking. Above all, every citizen in the country has the chance to contribute his/her ideas on how to govern the country, 
and every good idea has the chance to be adopted as a law or a policy. It creates a political system which is truly democratic and participatory.

\subsection{Governing Aid to Poor Nations}

Poverty is one of the biggest threats to global stability and human civilisation as a whole. According to latest report from the World Bank, "almost half the world's population - 3.4 billion people - still struggles to meet basic needs" [23], without even considering housing needs. According to latest report by Credit Suisse [24], the richest 1\% own $45 \%$ of the world's wealth while the bottom half of wealth holders collectively accounted for less than $1 \%$. In another report, it shows that $1.8 \%$ of the global population own $86.4 \%$ of the overall wealth [25]. These figures are staggering, they show that the world is at the tipping point. Unless extreme poverty and inequality are addressed, the world will never be at peace, let alone in harmony. The international communities' efforts on helping poor nations so far have been shadowboxing. So long as partisan politics plague like virus, poverty and inequality will only get worse until catastrophe strikes. The fourth principle of YaoShunism is to address these issues.

Most nations in the world will be able to heal themselves from toxic politics and return to healthy development once political parties are banned. However, for a small number of nations who have been wrecked by wars, violence and partisan politics for so long, external governing aid can be provided through UN. The aid will focus on governing assistance and economic management instead of just financial aids. The financial aids currently provided by developed nations often feed to corruption and lead to aid dependency. In contrast, governing aid aims to get a nation on its feet and help its people to achieve self-reliance.

Before requesting for aid, however, the nation should ban all political parties and install YaoShunism. On request from a nation for governing aid, the UN sets up a project on the aid. The UN then selects a project team from member nations which have good economic management records. The team works with the nation requesting for aid to develop an economic management plan or a program plan. The team then helps the nation to implement the plan until the nation has a competent government and is on track of economic recovery. The purpose of the aid is to develop the economy and train government personnel for the nation under aid. The operations of the aid must be transparent and be monitored by the UN throughout the entire project. 
Financial aids to poor nations from developed nations and international organizations should all be channelled to the UN. The UN then uses the money to set up funds for providing governing aids on request.

\section{Discussions}

Partisan politics has been played for hundreds of years, its weakness has been widely exposed, a change to its practice is inevitable just like the monarchies before it. At this moment, the world is dominated by two types of partisan politics, i.e., liberal democracy and authoritarianism. Political systems based on the two types of politics are engaged into a struggle for supremacy. Each of the two systems sees itself as superior to the other and sees the collapse of the other as inevitable. But the reality is that both types of systems are fundamentally flawed as shown in this article and both types of politics are under tremendous pressure to change.

There is strong resistance to change within political parties for fear of losing control or powers. Those who want to do business as usual would argue for their achievements on development, but people are shouting: at what cost? People's power should not be underestimated. Lessons have been learnt from Arab Spring and other violence around the world for resisting changes. The current refugee crisis and climate movement around the globe are also wake-up calls to politicians who want to keep status quo.

Now, both of the two systems are given the opportunity to morph into YaoShunism to avoid a fatal crisis. In that sense, YaoShunism provides a soft landing model for current politics. For people of the world, especially people of the third world, the change to YaoShunism means hope and blessing. For example, refugees will return to their own countries to start anew rather than languish in a foreign country; governments will be able to focus on improving people's wellbeing rather than focus on fighting off political opponents.

\section{Conclusions}

In this article, a new and practical political approach called YaoShunism, a contemporary version of YaoShun's democracy, is proposed. We first demonstrate that the root causes of political debacles around the world are due to political parties and elections. Next, we take a historical journey to look for oriental practice of democracy in ancient China. It is found that 
Yao the Great and Shun the Great together founded the first democracy in history. Based on this discovery, a new political frame work is formulated as YaoShunism, which is characterised by non-partisan, non-manipulation, merit-based governance and blessing to all. YaoShunism is a middle ground between liberal democracy and authoritarianism, both of which are extreme politics. YaoShunism offers participatory politics instead of exclusive politics by existing approaches, and it is backed by both Taoism and Confucianism, two of the best schools of philosophies in the world. YaoShunism gives opportunities as well as hope to every citizen in the world. It provides an avenue for exploring non-partisan governance and oriental wisdom on democracy.

\section{References:}

[1] Thwink, The Broken Political System Problem, https://www.thwink.org/sustain/glossary/ BrokenProblem.htm, accessed 2019.

[2] Jennifer Nini, Toxic Politics: Whatever Happened to Civility in Political Discourse? Eco Warrior Princess, 2018.

[3] John J. Mearsheimer, Bound to Fail: The Rise and Fall of the Liberal International Order, International Security, 2019.

[4] Dambisa Moyo, Why Democracy Doesn’t Deliver, Foreign Policy, 2018.

[5] Criticism of Democracy, https://en.wikipedia.org/wiki/Criticism_of_democracy, 2019.

[6] Sean Illing, Why Almost Everything You Think About Democracy Is Wrong, VOX, 2017.

[7] David Tormsen, 10 Alternatives to Conventional Liberal Democracy, Listverse, https://listverse.com/2016/02/10/10-alternatives-to-conventional-liberal-democracy/, accessed 2019.

[8] David S. Law, Alternatives to Liberal Constitutional Democracy, 77 Maryland Law Review 223 (2017), https://papers.ssrn.com/sol3/papers.cfm?abstract_id= 3087244, accessed 2019.

[9] Wikipedia, Voter Turnout, https://en.wikipedia.org/wiki/Voter_turnout, accessed 2019.

[10] Ben Millington, Fines and Court: What Can Happen if You Don't Vote, https://www.abc.net.au/news/2017-08-08/what-happens-when-you-dont-vote-in-afederal-election/8786684, accessed 2019. 
[11] Australian Electoral Commission, Electoral Backgrounder: Compulsory Voting, https://www.aec.gov.au/About_AEC/Publications/backgrounders/compulsoryvoting.htm, accessed 2019.

[12] Farnam Street Media, Tyranny, Democracy, and the Polity: Aristotle's Politics, https://fs.blog/2017/02/aristotles-politics/, accessed 2019.

[13] Encyclopaedia Britannica, Political Theory, https://www.britannica.com/biography/ Aristotle/Political-theory, accessed 2019.

[14] Wikipedia, Albert Einstein and Politics, https://en.wikiquote.org/wiki/Albert_Einstein_ and_politics, accessed 2019.

[15] Lao Tzu (老子), Tao Te Ching (道德经), https://www.chinasoul.org/documents/ 20182/82799/Tao+Te+Ching+Print+66991TTC.pdf, pp.36, https://ctext.org/dao-de-jing/ ens, accessed 2019.

[16] Analects of Confucius (论语), https://ctext.org/analects, accessed 2019.

[17] Sima Qian, Records of the Grand Historian (史记), https://ctext.org/shiji/wu-di-ben-ji, accessed 2019.

[18]Economist (2019), Karl Popper on democracy, https://www.economist.com/democracyin-america/2016/01/31/from-the-archives-the-open-society-and-its-enemies-revisited, accessed 7 Nov. 2019.

[19] The Book of Changes (周易), https://ctext.org/book-of-changes/xi-ci-xia/ens, accessed 2019.

[20] The Book of Rites (礼记), https://ctext.org/liji/da-xue/ens, accessed 2019.

[21] Lauren Leatherby and Mira Rojanasakul, Elected Leaders Are Making the World Less Democratic, https://www.bloomberg.com/graphics/2018-democracy-decline/, accessed 2019.

[22] Wikipedia, Imperial Examination, https://en.wikipedia.org/wiki/Imperial_examination, accessed 2019.

[23] World Bank, Nearly Half the World Lives on Less than $\$ 5.50$ a Day, https://www.worldbank.org/en/news/press-release/2018/10/17/nearly-half-the-worldlives-on-less-than-550-a-day, accessed 2019.

[24] Credit Suisse Research Institute, Global Wealth Report 2019, https://www.creditsuisse.com/about-us/en/reports-research/global-wealth-report.html, accessed 2019.

[25] International inequality, https://en.wikipedia.org/wiki/International_inequality\#cite_ note-4, accessed 2019. 